\title{
PENGEMBANGAN MEDIA PEMBELAJARAN BERBASIS GEOGEBRA UNTUK PEMBELAJARAN PERSAMAAN LINIER DUA VARIABEL DI SMP
}

\author{
I.P.D. Putra, Sariyasa, I.N. Sukajaya \\ Jurusan Pendidikan Matematika \\ Universitas Pendidikan Ganesha Singaraja, Indonesia \\ e-mail: donaputu21@gmail.com, sariyasa64@yahoo.com, suka23511@gmail.com
}

\begin{abstract}
Abstrak
Penelitian pengembangan ini bertujuan untuk: (1) Mendeskripsikan rancangan media pembelajaran persamaan linier dua variabel; (2) Mendeskripsikan hasil implementasi media pembelajaran menggunakan GeoGebra sebagai media eksplorasi, Lectora Inspire sebagai aplikasi pembuat layout dan latihan soal; (3) Mengetahui kevalidan, kepraktisan, dan keefektifan media Pembelajaran persamaan linier dua variabel. Model pengembangan yang digunakan adalah Model ADDIE yang terdiri dari tahap analysis, design, develop, implementation, evaluation. Teknik analisis data yang digunakan adalah teknik analisis data deskriptif kualitatif dan deskriptif kuantitatif. Hasil penelitian menunjukkan bahwa media pembelajaran yang dikembangkan dapat diterima sebagai media pembelajaran dengan rata-rata skor dari ahli perangkat pembelajaran sebesar 2,70 dengan kriteria valid, dan rata-rata skor dari ahli materi sebesar 2,66 dengan kriteria valid. Rata-rata skor kepraktisan media pembelajaran berdasarkan analisis angket respon siswa sebesar 3,24 dengan kriteria baik dan rata-rata kepraktisan berdasarkan angket respon guru sebesar 3,30 dengan kriteria baik. Persentase skor efektivitas dari kelompok siswa yang dipilih secara random sebesar $93,33 \%$ dan telah memenuhi kriteria ketuntasan klasikal. Berdasarkan hasil penelitian tersebut dapat disimpulkan bahwa media yang dikembangkan dapat diterima sebagai media pembelajaran dan diharapkan dapat digunakan sebagai media pembelajaran pada topik bahasan persamaan linier dua variabel baik oleh siswa maupun guru.
\end{abstract}

Kata kunci: media pembelajaran, persamaan linier dua variabel, gogebra.

\begin{abstract}
This developmental research was aimed to: (1) Describe the learning media design of two variable linear equations; (2) Describe the results of instructional media implementation using GeoGebra as an exploration media, Lectora Inspire as application of layout maker and exercise about; (3) Determine the validity, practicability, and effectiveness of media Learning of two variable linear equations. ADDIE model was used in this developmental research which consists of analysis, design, develop, implementation, evaluation. Descriptive qualitative and quantitative data analyses were used in this research. The results showed that the learning media developed can be accepted as a media of learning with the average score of the expert learning device of 2.70 with valid criteria, and the average score of the material experts of 2.66 with valid criteria. The average score of practicality of learning media based on student response questionnaire of 3.24 with practical criteria and practicality average score based on teacher response questionnaire by 3.30 with practical criteria. Percentage effectiveness score of randomly selected group of students is $93.33 \%$ and has fulfilled the criteria of classical completeness. Based on the result of this research, it can be concluded that the developed media can be accepted as learning media and expected to be used as learning media in the topic two variable linear equations by both students and teachers.
\end{abstract}

Keyword: learning media, two variable linear equations, geogebra 
Jurnal Pendidikan dan Pembelajaran Matematika Indonesia

Vol. 7 No. 1, Tahun 2018

e-ISSN : 2615-7454

\section{Pendahuluan}

Undang-Undang Sistem Pendidikan Nasional No. 20 Tahun 2003 menyatakan bahwa pembelajaran adalah proses interaksi peserta didik dengan pendidik dan sumber belajar pada suatu lingkungan belajar. Pembelajaran di sekolah mencakup berbagai mata pelajaran salah satunya adalah mata pelajaran matematika. Menurut Suherman (2003:55) matematika sekolah merupakan matematika yang diajarkan pada jenjang pendidikan dasar dan pendidikan menengah dengan objek kejadian yang abstrak serta pola pikir deduktif yang konsisten. Sedangkan menurut Ebbutt dan Straker (Marsigit, 2013:15) matematika sekolah didefinisikan sebagai kegiatan eksplorasi mencari pola, kegiatan menyelesaikan masalah, dan kegiatan berkomunikasi. Menurut Jerome Bruner dalam Erman Suherman (2003:43), mengatakan bahwa belajar matematika akan lebih berhasil jika proses pengajaran diarahkan pada konsep-konsep dan struktur-struktur yang termuat dalam pokok bahasan yang diajarkan, disamping hubungan yang terkait antara konsep-konsep dan struktur-struktur. Oleh karena itu belajar matematika yang ideal haruslah bertahap, berurutan dan berdasarkan pada pengalaman belajar sebelumnya yang sesuai dengan tahapan perkembangan kognitif peserta didik.

Untuk dapat membelajarkan matematika, Bruner (Suherman, 2003) mengungkapkan bahwa dalam proses belajar, siswa sebaiknya diberi kesempatan memanipulasi bendabenda atau alat peraga yang dirancang secara khusus yang dapat dieksplorasi oleh siswa dalam memahami suatu konsep matematika. Melalui alat peraga atau media yang dieksplorasi, siswa akan melihat langsung bagaimana keteraturan dan pola struktur yang terdapat dalam media pembelajaran yang sedang diperhatikannya. Di antara media pembelajaran yang ada, terdapat suatu media pembelajaran yang diyakini lebih efektif dan mampu menjembatani ranah pemikiran siswa dari kongkret ke abstrak. Dalam penelitian yang dilakukan oleh I Gusti Lanang Adhi Wirasena (2012), diketahui bahwa media pembelajaran interaktif berbasis komputer dianggap efektif dan layak dikembangkan karena media ini memberikan kesempatan kepada siswa untuk bebas bereksplorasi. Hal ini sejalan dengan Permendikbud Nomor 65 Tahun 2013 Tentang Standar Proses yang menyebutkan salah satu prinsip pembelajaran yang digunakan yang sesuai dengan Standar Kompetensi Lulusan dan Standar Isi adalah pemanfaatan teknologi informasi dan komunikasi untuk meningkatkan efisiensi dan efektivitas pembelajaran.

Konsep pembelajaran dengan menggunakan teknologi informasi dan komunikasi khusunya komputer di mana siswanya berinteraksi langsung dengan komputer dikenal dengan istilah Computer Assisted Instruction (CAI). Menurut Mustiqon (2012:190) dalam konsep CAI komputer difungsikan sebagai penyaji materi pembelajaran, penyimpan materi pelajaran, hingga memberikan analisis evaluasi pembelajaran. Penerapan pembelajaran berbasis komputer salah satunya adalah dengan memanfaatkan berbagai software komputer yang dapat digunakan untuk membuat berbagai media pembelajaran. Pembelajaran dengan media berbasis komputer memiliki kelebihan dalam menyajikan materi pelajaran secara visual, audio, dan kinestetik sehingga pembelajaran menjadi lebih menarik, efektif, dan efisien serta diharapkan mampu meningkatkan pencapaian hasil belajar matematika peserta didik.

Berdasarkan analisis awal yang dilakukan, ditemukan bahwa dalam pembelajaran persamaan linear dua variabel, siswa mengalami kesulitan dalam merumuskan model matematika beserta penyeslesaian permasalahan sistem persamaan linier dua variabel. Seringkali siswa ditunjukkan tentang cara penyelesaian persamaan linear dua variabel berdasarkan rumus tanpa memberikan kesempatan kepada siswa untuk menemukan sendiri konsep penyelesaian sistem persamaan linier dua variabel. Dari hasil wawancara juga diketahui bahwa dalam pembelajaran matematika guru sudah menggunakan media pembelajaran berupa slide show yang dikembangkan menggunakan software PowerPoint. Namun media tersebut penggunaannya masih berpusat pada guru dan kurang eksploratif karena hanya berupa slide yang memaparkan teks dan gambar saja. Sedangkan dalam Kurikulum 2013 yang berlaku saat ini dituntut pola pembelajaran yang berpusat pada siswa dan siswa aktif mencari atau mengeksplorasi sendiri pengetahuan yang dibutuhkan. Selain 
menggunakan media berupa slide show, guru juga telah melakukan berbagai cara untuk membantu siswa, salah satunya dengan menggunakan alat peraga sebagai penunjang lainnya dalam pembelajaran. Namun jika ditelaah lebih mendalam, alat peraga memiliki fungsi yang sangat terbatas. Selain fungsinya yang terbatas, jumlah yang disediakan tiap sekolah juga terbatas karena memperhitungkan biaya penyediaan dan tempat penyimpanan.

Media pembelajaran persamaan linier dua variabel sangat baik digunakan untuk membelajarkan matematika jika dibandingkan dengan alat peraga dan slide show. Media pembelajaran mampu menampilkan visualisasi dari konsep-konsep yang cenderung abstrak atau sulit dipahami oleh siswa, seperti konsep metode eliminasi dan substitusi. Untuk membuat visualisasi yang eksploratif dari konsep tersebut dapat digunakan software khusus matematika, yakni GeoGebra. Media juga memuat musik atau narasi yang dapat memperkuat penjelasan berupa teks yang muncul pada layar komputer. Sebagai proses evaluasi siswa, media memuat latihan-latihan soal yang bisa dijawab siswa secara langsung dan skor akan muncul dengan sendirinya setelah siswa selesai menjawab soal. Hal ini membuat siswa dapat mengetahui sejauh mana dirinya menguasai materi yang disajikan dalam media pembelajaran. Guru dan siswa pun tidak perlu repot untuk mengakses media pembelajaran karena dapat disimpan dalam sebuah flashdisk atau CD (Compact Disk). Kemudahan akses dan adanya proses evaluasi dalam media pembelajaran menjadikan media pembelajaran sangat baik digunakan sebagai fasilitas untuk belajar mandiri.

Kelebihan media pembelajaran persamaan linier dua variabel dibandingkan dengan media pembelajaran lainnya adalah mampu memuat banyak sub materi sehingga fungsinya tidak terbatas untuk membelajarkan satu sub materi saja. Media pembelajaran ini juga mampu menjangkau gaya belajar siswa yang beragam, menghilangkan kebosanan siswa, dan sangat baik untuk kegiatan belajar mandiri. Media pembelajaran yang memuat unsur gambar, suara, dan media eksploratif tentunya akan lebih banyak melibatkan alat indera peserta didik sehingga lebih meningkatkan daya ingat mereka. Walter Mc Kenzie (dalam Musfiqon, 2012:32) menyatakan bahwa media memiliki peran penting dalam pembelajaran di kelas, yang mempengaruhi kualitas dan keberhasilan pembelajaran. Optimalisasi penggunaan media dalam pembelajaran dapat mendorong tercapainya hasil belajar yang lebih optimal. Guru dan siswa sama-sama dapat belajar dan menguasai materi dengan bantuan media yang telah disesuaikan dengan isi dan tujuan pembelajaran. Arsyad (2010:16) menyatakan penggunaan media pembelajaran pada tahap orientasi pembelajaran akan sangat membantu keefektifan pembelajaran dan penyampaian pesan dan isi pembelajaran.

Berdasarkan dampak positif tersebut maka perlu berbagai inovasi kreatif dalam menciptakan media yang dapat digunakan sebagai media pembelajaran yang inovatif dan eksploratif sehingga bisa dimanfaatkan di dunia pendidikan guna mendukung kegiatan belajar mengajar dan menarik minat belajar peserta didik. Salah satu program komputer yang dapat dimanfaatkan sebagai media pembelajaran matematika adalah program GeoGebra. GeoGebra dikembangkan oleh Markus Hohenwarter pada tahun 2001. Menurut Hohenwarter dan Judith Hohenwarter (2008) GeoGebra adalah program komputer untuk membelajarkan matematika yang dinamis dan interaktif untuk pembelajaran dan penyelesaian soal-soal matematika khususnya geometri, aljabar, dan kalkulus. Dengan beragam fasilitas yang dimiliki, GeoGebra dapat dimanfaatkan sebagai media pembelajaran matematika untuk mendemontrasikan atau memvisualisasikan konsep-konsep matematis serta sebagai alat bantu untuk mengkonstruksi konsep-konsep matematis.

Saat ini fasilitas pendukung pembelajaran berbasis teknologi informasi seperti laboratorium komputer sebagian besar sudah dimiliki oleh sekolah-sekolah sehingga sangat mendukung pembelajaran dengan menggunakan multimedia. Penerapan pembelajaran dengan menggunakan multimedia ini dapat menumbuhkan kompetensi pedagogi dan profesional seorang guru khususnya dalam pemanfaatan teknologi informasi dan komunikasi untuk kepentingan pembelajaran dan pengembangan diri.

Rumusan masalah pada penelitian pengembangan ini adalah: 1) Bagaimana rancangan pengembangan media pembelajaran persamaan linier dua variabel berbasis GeoGebra? 2) 
Bagaimana implementasi media pembelajaran persamaan linier dua variabel menggunakan GeoGebra sebagai aplikasi pembuat media eksplorasi, Lectora Inspire sebagai aplikasi pembuat Layout dan latihan soal? 3) Apakah media pembelajaran persamaan linier dua variabel yang dikembangkan valid, praktis, dan efektif digunakan dalam pembelajaran matematika?

Sesuai rumusan masalah di atas maka penelitian dan pengembangan ini memiliki tujuan sebagai berikut: 1) rancangan pengembangan media pembelajaran persamaan linier dua variabel berbasis GeoGebra, 2) implementasi media pembelajaran persamaan linier dua variabel menggunakan GeoGebra sebagai aplikasi pembuat media eksplorasi, Lectora Inspire sebagai aplikasi pembuat Layout dan latihan soal, 3) Mengetahui kevalidan, kepraktisan, dan keefektifan media pembelajaran persamaan linier dua variabel.

Berdasarkan uraian diatas penulis merasa perlu untuk melaksanakan penelitian pengembangan media pembelajaran matematika berbasis GeoGebra khususnya media pembelajaran untuk materi persamaan linier dua variabel. Media pembelajaran yang akan penulis kembangkan adalah media pembelajaran yang dapat digunakan oleh guru dengan menggunakan model pembelajaran apapun, sehingga dapat memudahkan guru dalam melaksanakan pembelajaran di kelas dengan menggunakan media pembelajaran tersebut. Untuk itu penulis melakukan penelitian pengembangan dengan judul "Pengembangan Media Pembelajaran Berbasis GeoGebra Untuk Pembelajaran Persamaan Linier Dua Variabel di SMP".

\section{Metode}

Penelitian ini dilakukan dengan pendekatan penelitian dan pengembangan (Research and Development). Penelitian pengembangan adalah suatu proses yang dipakai untuk mengembangkan dan memvalidasi produk pendidikan (Punaji Setyosari, 2010:207). Penelitian ini bertujuan untuk menghasilkan produk penelitian berupa media berbasis GeoGebra.

Model penelitian pengembangan yang digunakan dalam pengembangan media pembelajaran persamaan linier dua variabel berbasis GeoGebra adalah model ADDIE. Pemilihan model ini didasari atas pertimbangan bahwa model ini mudah untuk dipahami, selain itu juga model ini dikembangkan secara sistematis dan berpijak pada landasan teoritis desain pembelajaran yang dikembangkan. Model ini disusun secara terprogram dengan kegiatan yang sistematis dalam upaya pemecahan masalah belajar yang berkaitan dengan media belajar yang sesuai dengan kebutuhan dan karakteristik siswa.

Model pengembangan ADDIE memiliki kelebihan dibandingkan model pengembangan lainnya seperti efesiensi langkah pengembangan yang terdiri dari 5 tahap. Tegeh \& Kirna (2010) menyatakan tahapan penelitian pengembangan pada model ADDIE yaitu: (1) Analysis (Analisis), (2) Design (Perancangan), (3) Development (Pengembangan), (4) Implementation (Implementasi), dan (5) Evaluation . Selengkapnya, alur tahapan penelitian pengembangan model ADDIE dalam Tegeh dan Kirna (2010) ditunjukan pada Gambar 1 berikut. 


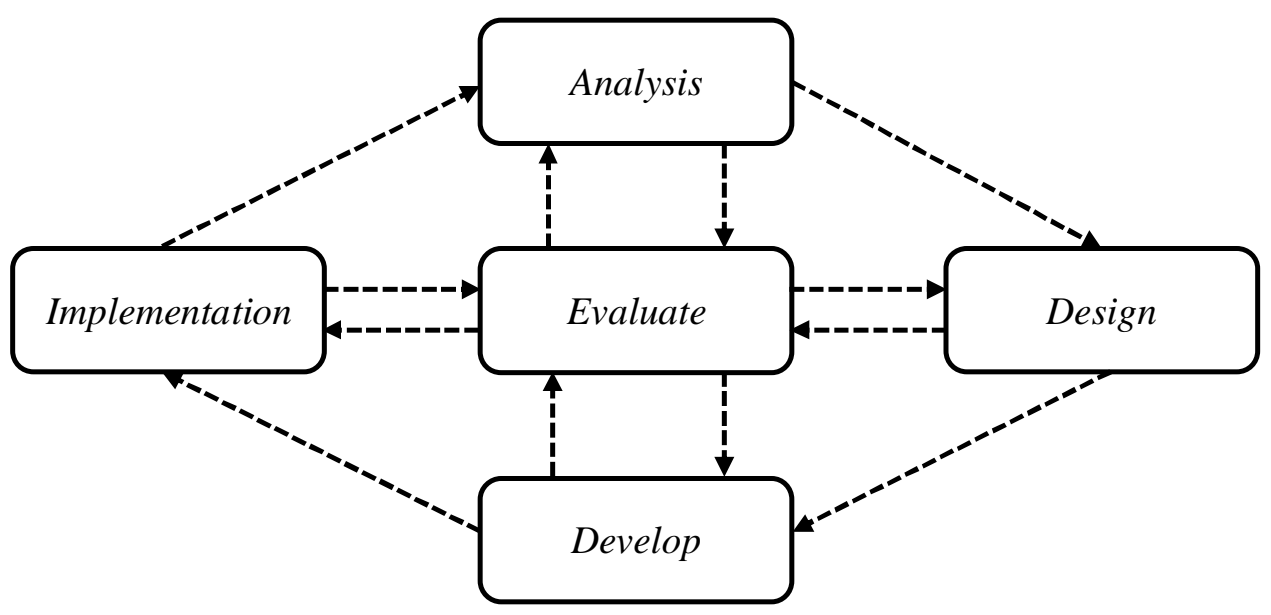

Gambar 1. Tahapan Model ADDIE dalam Tegeh \& Kirna (2010)

Kegiatan utama pada tahap analisis adalah analisis awal dan analisis kurikulum. Analisis awal dilakukan untuk mengetahui permasalahan-permasalahan yang terjadi di lapangan khususnya dalam proses pembelajaran matematika topik bahasan persamaan linier dua variabel. Tahap desain dilakukan untuk merancang media pembelajaran persamaan linier dua varibel berbasis GeoGebra dan alat evaluasinya. Tahap pengembangan dalam model ADDIE berisi kegiatan realisasi rancangan produk. Dalam tahap desain, telah disusun kerangka desain pembelajaran pada media, dirancang desain visual media, beserta desain tampilan dari media yang dikembangkan. Dalam tahap pengembangan, kerangka yang masih konseptual tersebut direalisasikan menjadi produk yang siap diimplementasikan.

Dalam tahap ini dilakukan pengembangan rancangan media pembelajaran berbasis GeoGebra yang menggunakan software Lectora sebagai layout dari media.

Software Lectora ini dapat dimodifikasi untuk membuat apersepsi dan petunjuk penggunaan media sebelum memulai media dan latihan soal setelah penggunaan media persamaan linier dua variable. Pada tahap ini juga dilakukan kegiatan uji ahli perangkat pembelajaran dan ahli materi yang bertujuan untuk mengetahui validitas terhadap media yang telah dirancang. Ahli yang dipilih adalah seseorang yang memiliki pengetahuan ataupun kemampuan dalam bidang studi tertentu didasarkan pada pendidikan, profesi, pengalaman, dan prestasi yang pernah diraih. Uji ahli melibatkan 2 orang ahli yaitu dua orang dosen Jurusan Pendidikan Matematika Undiksha sebagai ahli materi (desain pembelajaran) dan ahli media. Media pembelajaran ini dikatakan valid jika rata-rata skor validitasnya berada pada rentang $\bar{X}_{i}+S D_{i}<X$. Setelah media berbasis GeoGebra ini dinilai, diperbaiki, kemudian sudah dinyatakan valid maka selanjutnya media ini di implementasikan.

Sampel yang digunakan dalam uji coba terbatas adalah 10-20 orang siswa yang mencerminkan karakteristik populasi (Tegeh dan Kirna, 2010). Berdasarkan hal tersebut sampel yang digunakan dalam pengembangan ini adalah siswa kelas VII sebanyak 15 siswa yang dalam hal ini siswa yang sudah mendapatkan materi prasyarat (persamaan linier satu variabel) dan belum sekalipun mendapatkan materi persamaan linier dua variabel. Pemilihan kelas dan siswa dilakukan dengan teknik random sampling. Peserta didik membentuk kelompok yang beranggotakan 2-3 orang siswa. Masing-msing kelompok diberikan sebuah komputer yang didalamnya sudah terinstalasi media pembelajaran persamaan linier dua variabel. Pada akhir pertemuan, peserta didik diminta untuk menjawab tes evaluasi dan mengisi angket respon peserta didik. Pada tahap ini akan diketahui kendala-kendala yang dihadapi saat pembelajaran dengan menggunakan media pembelajaran berbasis GeoGebra. Hasil respon peserta didik digunakan pula sebagai acuan untuk melakukan revisi media 
yang dikembangkan. Selain itu, pada tahap ini pendidik diminta untuk mengisi angket respon pendidik untuk mengetahui tingkat kepraktisan dari media yang dikembangkan.

Media yang telah diuji cobakan dilakukan kegiatan evaluasi. Langkah ini merupakan kegiatan klarifikasi data yang didapat dari angket berupa tanggapan dari guru dan peserta didik, serta terhadap kompetensi, pengetahuan dan ketrampilan dan sikap yang harus dimiliki oleh peserta didik setelah mengikuti kegiatan pembelajaran. Evaluasi yang dilakukan bertujuan untuk mengetahui efektivitas dan kepraktisan dari media yang dikembangkan. Media pembelajaran yang dikembangkan dikatakan efektif jika setelah mengikuti pembelajaran dengan menggunakan media yang dikembangkan ini siswa dalam kelas uji coba tuntas secara klasikal. Suatu kelas dikatakan tuntas belajarnya (ketuntasan klasikal) jika dalam kelas tersebut terdapat $\geq 85 \%$ siswa yang telah tuntas belajarnya (Trianto, 2010:241). Kemudian kriteria kepraktisan dari media ini dilihat dari keterlaksanaan di lapangan melalui angket respon siswa dan respon guru yang diberikan. Dengan kata lain, media pembelajaran dikatakan praktis apabila dapat dilaksanakan secara praktis di lapangan dengan kriteria minimal yang dicapai adalah baik yakni dengan rata-rata berada pada interval

$\bar{X}_{i}+0,6 S D_{i}<X \leq \bar{X}_{i}+1,8 S D_{i}$.

\section{Hasil dan Pembahasan}

Kualitas produk media pembelajaran yang dikembangkan dalam penelitian ini didasarkan pada tiga aspek, yaitu validitas, kepraktisan, dan keefektifan. Berikut akan diuraikan hasil validitas, kepraktisan, dan keefektifan dari Media Pembelajaran Persamaan Linier Dua Variabel.

Validasi media pembelajaran dilakukan setelah peneliti menghasilkan Media dalam bentuk Prototype I. Validasi dilakukan oleh ahli perangkat pembelajaran dan ahli materi dengan cara memberikan penilaian dan saran terhadap Media pembelajaran dengan mengisi angket penilaian kelayakan.

Ahli perangkat pembelajaran dan ahli materi yang ditunjuk sebagai validator media pembelajaran yang dikembangkan adalah dua orang dosen di Jurusan Pendidikan Matematika Undiksha yang berkompeten dalam bidang media pembelajaran. Hasil uji validitas media pembelajaran oleh ahli perangkat pembelajaran dan ahli materi secara berturut-turut disajikan pada Tabel 1 dan Tabel 2 berikut.

Tabel 1. Hasil Uji Validitas Media Pembelajaran Oleh Ahli Perangkat Pembelajaran

\begin{tabular}{cllcc}
\hline No. & \multicolumn{1}{c}{ Aspek Penilaian } & $\begin{array}{c}\text { Skor } \\
\text { Ahli 1 }\end{array}$ & $\begin{array}{c}\text { Skor } \\
\text { Ahli 2 }\end{array}$ & $\begin{array}{c}\text { Rata- } \\
\text { rata } \\
\text { Skor }\end{array}$ \\
\hline A. & Aspek prangkat lunak & & & 3 \\
\hline 1. & $\begin{array}{l}\text { Maintable (dapat dipelihara/dikelola } \\
\text { dengan mudah) }\end{array}$ & 3 & 3 & 3 \\
\hline $2 . \quad \begin{array}{l}\text { Usable (mudah digunakan dan } \\
\text { sederhana pengoperasiannya) }\end{array}$ & 3 & 3 & 3 \\
\hline 3. $\quad \begin{array}{l}\text { Compatible (media pembelajaran } \\
\text { dapat diinstalasi atau dijalankan } \\
\text { diberbagai hardware dan software } \\
\text { yang ada) }\end{array}$ & 3 & 3 & 3 \\
\hline $4 . \quad \begin{array}{l}\text { Ketersediaan dan kejelasan petunjuk } \\
\text { instalasi dan petunjuk penggunaan } \\
\text { media }\end{array}$ & 3 & 3 & 3 \\
\hline $5 . \quad \begin{array}{l}\text { Reusable (sebagian atau seluruh } \\
\text { program media pembelajaran dapat } \\
\text { dimanfaatkan kembali untuk } \\
\text { mengembangkan media }\end{array}$ & 2 & 3 & 2,5 \\
\hline & & & & \\
\hline
\end{tabular}




\begin{tabular}{|c|c|c|c|c|}
\hline & pembelajaran lain) & & & \\
\hline B. & Aspek komunikasi visual & & & \\
\hline 6. & $\begin{array}{l}\text { Komunikatif, sesuai dengan pesan } \\
\text { dan dapat diterima dengan keinginan } \\
\text { sasaran }\end{array}$ & 3 & 2 & 2,5 \\
\hline 7. & Navigasi dalam pengoperasian media & 2 & 3 & 2,5 \\
\hline 8. & $\begin{array}{l}\text { Audio (narasi, sound effect, } \\
\text { backsound, musik) }\end{array}$ & 2 & 3 & 2,5 \\
\hline 9. & $\begin{array}{l}\text { Visual (Layout desain, tipografi, } \\
\text { warna) }\end{array}$ & 3 & 2 & 2,5 \\
\hline 10. & Animasi dan gambar dalam media & 2 & 3 & 2,5 \\
\hline & $\begin{array}{c}\text { Skor Total } \\
\text { Rata-rata Skor }\end{array}$ & $\begin{array}{c}26 \\
2,60\end{array}$ & $\begin{array}{c}28 \\
2,80\end{array}$ & 27 \\
\hline
\end{tabular}

Tabel 2. Hasil Uji Validitas Media Pembelajaran Oleh Ahli Materi

\begin{tabular}{llccc}
\hline No. & \multicolumn{1}{c}{ Aspek Penilaian } & $\begin{array}{c}\text { Skor } \\
\text { Ahli 1 }\end{array}$ & $\begin{array}{c}\text { Skor } \\
\text { Ahli 2 }\end{array}$ & $\begin{array}{c}\text { Rata- } \\
\text { rata } \\
\text { Skor }\end{array}$ \\
\hline A. & Aspek desain pembelajaran & & & \\
\hline 1. & $\begin{array}{l}\text { Kesesuaian materi yang disajikan } \\
\text { dalam media pembelajaran dengan } \\
\text { kompetensi dasar }\end{array}$ & 3 & 3 & 3 \\
\hline 2. & Kontekstualitas & 3 & 3 & 3 \\
\hline 3. & Kedalaman dan kelengkapan materi & 3 & 2 & 2,5 \\
\hline 4. & Kemudahan materi untuk dipahami & 2 & 2 & 2 \\
\hline 5. & Sistematis, runtut, alur logis, dan jelas & 2 & 3 & 2,5 \\
\hline 6. & $\begin{array}{l}\text { Isi media pembelajaran secara } \\
\text { keseluruhan dapat membantu dalam } \\
\text { kegiatan pembelajaran }\end{array}$ & 3 & 3 & 3 \\
$\quad$ Skor Total & $\mathbf{1 6}$ & $\mathbf{1 6}$ & $\mathbf{1 6}$ \\
\hline$\quad$ Rata-rata Skor & $\mathbf{2 , 6 6}$ & $\mathbf{2 , 6 6}$ & $\mathbf{2 , 6 6}$ \\
\hline
\end{tabular}

Kepraktisan media pembelajaran yang dikembangkan dalam penelitian ini dilihat dari skor angket respons siswa dan angket respons guru terhadap media pembelajaran yang diambil di bagian akhir kegiatan uji coba. Selanjutnya dipaparkan data mengenai kepraktisan media pembelajaran yang dikembangkan. Data dan analisis angket respons siswa dan guru setelah menggunakan media pembelajaran yang dikembangkan dalam penelitian ini secara berturut-turut dapat dilihat pada Tabel 3 dan Tabel 4 berikut.

Tabel 3. Hasil Analisis Angket Respon Siswa

\begin{tabular}{ccccccccccccc}
\hline & \multicolumn{1}{c}{ Kode Siswa } & \multicolumn{1}{c}{ No. Pernyataan } & \multicolumn{1}{c}{$\begin{array}{c}\text { Skor } \\
\text { Total }\end{array}$} \\
\cline { 2 - 11 } & $\mathbf{1}$ & $\mathbf{2}$ & $\mathbf{3}$ & $\mathbf{4}$ & $\mathbf{5}$ & $\mathbf{6}$ & $\mathbf{7}$ & $\mathbf{8}$ & $\mathbf{9}$ & $\mathbf{1}$ & $\mathbf{1}$ & \\
\hline A & 4 & 4 & 3 & 3 & 3 & 4 & 3 & 3 & 3 & 3 & 4 & 37 \\
\hline B & 4 & 3 & 3 & 3 & 3 & 4 & 3 & 3 & 4 & 3 & 3 & 36 \\
\hline C & 4 & 3 & 3 & 4 & 3 & 3 & 3 & 4 & 3 & 4 & 3 & 37 \\
\hline D & 3 & 3 & 3 & 4 & 3 & 3 & 4 & 3 & 4 & 4 & 4 & 38 \\
\hline E & 3 & 3 & 3 & 3 & 2 & 3 & 3 & 3 & 3 & 3 & 3 & 32 \\
\hline
\end{tabular}




\begin{tabular}{ccccccccccccc} 
F & 3 & 4 & 4 & 3 & 3 & 3 & 3 & 3 & 3 & 3 & 3 & 35 \\
\hline G & 4 & 3 & 3 & 3 & 3 & 3 & 3 & 3 & 3 & 4 & 4 & 36 \\
\hline $\mathbf{H}$ & 3 & 3 & 3 & 3 & 2 & 3 & 3 & 2 & 2 & 3 & 3 & 30 \\
\hline $\mathbf{I}$ & 4 & 4 & 3 & 3 & 3 & 3 & 4 & 3 & 2 & 3 & 3 & 35 \\
\hline $\mathbf{J}$ & 3 & 4 & 3 & 4 & 3 & 3 & 4 & 3 & 3 & 3 & 4 & 37 \\
\hline $\mathbf{K}$ & 3 & 4 & 3 & 3 & 3 & 4 & 4 & 3 & 3 & 3 & 3 & 36 \\
\hline $\mathbf{L}$ & 3 & 4 & 3 & 3 & 4 & 4 & 3 & 3 & 3 & 3 & 3 & 36 \\
\hline $\mathbf{M}$ & 3 & 3 & 3 & 4 & 3 & 3 & 4 & 4 & 4 & 4 & 3 & 38 \\
\hline $\mathbf{N}$ & 3 & 3 & 4 & 4 & 3 & 3 & 3 & 4 & 3 & 3 & 4 & 37 \\
\hline O & 4 & 3 & 3 & 3 & 3 & 3 & 4 & 3 & 4 & 3 & 3 & 36 \\
\hline \multirow{8}{*}{ Total Skor } & $\mathbf{5}$ & $\mathbf{5}$ & $\mathbf{4}$ & $\mathbf{5}$ & $\mathbf{4}$ & $\mathbf{4}$ & $\mathbf{5}$ & $\mathbf{4}$ & $\mathbf{4}$ & $\mathbf{4}$ & $\mathbf{5}$ & \multirow{5}{*}{ Rata-rata Skor } \\
& $\mathbf{1}$ & $\mathbf{1}$ & $\mathbf{7}$ & $\mathbf{0}$ & $\mathbf{4}$ & $\mathbf{9}$ & $\mathbf{1}$ & $\mathbf{7}$ & $\mathbf{7}$ & $\mathbf{9}$ & $\mathbf{0}$ & \\
\hline & Rata-rata Skor Total & & & & & & $\mathbf{3 5 , 7 3}$ \\
\hline
\end{tabular}

Tabel 4. Hasil Analisis Angket Respon Guru

No.

Item Pernyataan

Skor

\begin{tabular}{|c|c|c|}
\hline 1. & Petunjuk instalasi media sudah disediakan dan sudah jelas & 4 \\
\hline 2. & $\begin{array}{l}\text { Materi yang disajikan dalam media sudah sesuai dengan } \\
\text { kompetensi dasar }\end{array}$ & 3 \\
\hline 3. & $\begin{array}{l}\text { Jenis dan ukuran huruf yang digunakan dalam media sudah } \\
\text { sesuai dan mudah untuk dibaca }\end{array}$ & 3 \\
\hline 4. & $\begin{array}{l}\text { Bahasa yang digunakan dalam media sudah baik dan mudah } \\
\text { untuk dipahami }\end{array}$ & 3 \\
\hline 5. & $\begin{array}{l}\text { Navigasi (home, bantuan, keluar, kembali, dan lanjut) dalam } \\
\text { pengoperasian media sudah runtut dan mudah dijalankan }\end{array}$ & 4 \\
\hline 6. & Petunjuk penggunaan media sudah disediakan dan sudah jelas & 4 \\
\hline 7. & $\begin{array}{l}\text { Latihan soal dalam media sudah sesuai dengan materi yang } \\
\text { disajikan }\end{array}$ & 3 \\
\hline 8. & Penggunaan gambar dan animasi dalam media sudah tepat & 3 \\
\hline 9. & $\begin{array}{l}\text { Penggunaan warna dan kesesuaian resolusi gambar pada } \\
\text { media sudah baik }\end{array}$ & 3 \\
\hline 10 . & $\begin{array}{l}\text { Ketepatan pengembangan media persamaaan linier dua } \\
\text { variabel sudah sesuai }\end{array}$ & 3 \\
\hline & Skor Total & 33 \\
\hline & Rata-rata Skor & 3,30 \\
\hline
\end{tabular}

Keefektifan media pembelajaran dalam penelitian ini dilihat berdasarkan ketercapaian tujuan pembelajaran menggunakan media pembelajaran yang dikembangkan. Penilaian keefektifan media pembelajaran dalam penelitian ini diperoleh melalui tes. Tes yang diberikan berupa soal pilihan ganda sebanyak 15 butir yang diberikan di akhir proses pembelajaran menggunakan media pembelajaran berbasis GeoGebra yang dikembangkan. Hasil tes evaluasi siswa disajikan pada Tabel 5 berikut. 
Tabel 5. Hasil Tes Evaluasi Siswa

\begin{tabular}{ccc}
\hline Kode Siswa & Skor Tes & Keterangan \\
\hline A & 86,67 & Tuntas \\
\hline B & 80,00 & Tuntas \\
\hline D & 80,00 & Tuntas \\
\hline E & 93,34 & Tuntas \\
\hline F & 80,00 & Tuntas \\
\hline G & 86,67 & Tuntas \\
\hline H & 80,00 & Tuntas \\
\hline J & 73,34 & Tidak Tuntas \\
\hline K & 80,00 & Tuntas \\
\hline L & 80,00 & Tuntas \\
\hline M & 86,67 & Tuntas \\
\hline N & 80,00 & Tuntas \\
\hline O & 93,34 & Tuntas \\
\hline Rata-rata & 80,00 & Tuntas \\
\hline Skor Tertinggi & 80,00 & Tuntas \\
\hline Skor Terendah & 82,66 \\
\hline Jumlah Siswa Tuntas & 93,34 \\
\hline Jumlah Siswa Tidak Tuntas & & 73,34 \\
\hline Ketuntasan Klasikal & & 14 \\
\hline & & $93,33 \%$ \\
\hline
\end{tabular}

Pembuatan perangkat lunak media pembelajaran dalam penelitian ini menggunakan software GeoGebra, Camtasia Studio, dan Lectora Inspire. Software GeoGebra digunakan sebagai aplikasi pembuat media eksplorasi. GeoGebra adalah software yang digunakan untuk membelajarkan matematika, khususnya materi geometri dan aljabar. Media eksplorasi dalam media pembelajaran dirancang untuk menuntun siswa menemukan sendiri konsep yang digunakan untuk menentukan penyelesaian sistem persaman linier dua variabel.

Camtasia Studio digunakan sebagai aplikasi pengeditan pengisian backsound pada media pembelajaran. Camtasia Studio dapat digunakan untuk melakukan pengeditan sederhana, seperti memotong dan menggabungkan suara. Musik dapat digunakan untuk memberikan

isyarat atau timbal balik, menarik perhatian, membangkitkan minat, dan membantu dalam mengingat (Fahy, 2005). Selanjutnya keseluruhan media eksplorasi, gambar, dan backsound digabungkan dan didesain Layout-nya menjadi sebuah media pembelajaran yang utuh menggunakan aplikasi Lectora Inspire. Lectora Inspire adalah aplikasi pengembangan media pembelajaran elektronik. Konten yang dikembangkan Lectora Inspire dapat dipublikasikan menjadi HTML atau single file executable (.exe). Lectora Inspire juga memungkinkan pengguna untuk memanfaatkan berbagai file untuk membuat konten menjadi lebih menarik. Tampilan media pembelajaran yang dikembangkan didesain sederhana dan konsisten agar tidak membingungkan pengguna.

Lectora Inspire juga digunakan untuk pembuatan latihan soal yang disajikan dalam media pembelajaran. Pada Lectora Inspire sudah tersedia

pilihan berbagai macam jenis evaluasi, seperti soal benar salah, pilihan ganda, isian singkat, menjodohkan, dan esai. Untuk latihan soal dalam media pembelajaran yang dikembangkan dibuat dalam bentuk pilihan ganda. Hal ini dikarenakan tes pilihan ganda lebih representatif 
mewakili isi dan luas bahan atau dapat mencakup banyak materi. Program media pembelajaran yang telah selesai, dipublikasi ke dalam bentuk single file executable (.exe).

Berdasarkan hal tersebut maka dikembangkan suatu media pembelajaran persamaan linier dua variabel berbasis GeoGebra dengan Lectora sebagai aplikasi pembuat Layout dan latihan soal. Media yang dikembangkan dirancang agar menjadi media yang dapat membantu siswa dalam mempelajari materi persamaan linier dua variabel di kelas VIII SMP. Pembelajaran diharapkan menjadi lebih menarik dan lebih mengeksplor pengetahuan siswa serta meningkatkan prestasi belajar siswa untuk mengikuti pembelajaran dengan adanya media ini.

Kualitas media yang dikembangkan dalam penelitian ini mengacu pada Kriteria yang dikemukakan olen Nieveen (1999) yang berdasarkan tiga aspek penilaian, yaitu validitas (validity), kepraktisan (practicality), dan keefektifan (effectiveness). Validitas diketahui melalui evaluasi media oleh ahli media pembelajaran dan ahli desain pembelajaran, kepraktisan diketahui dari analisis angket respon siswa dan guru, dan keefektifan diketahui dari ketuntasan belajar siswa secara klasikal. Berikut adalah uraian tentang validitas, kepraktisan, dan efektivitas dari Media. Validitas Media Pembelajaran Persamaan Linier Dua Variabel berdasarkan hasil penilaian ahli perangkat pembelajaran berada pada kriteria baik, dengan rata-rata skor 2,70. Ahli perangkat pembelajaran menilai validitas media pembelajaran dari aspek perangkat lunak dan komunikasi visual. Dilihat dari aspek perangkat lunak, media pembelajaran yang dikembangkan dapat dikelola dengan mudah, pengoperasiannya sederhana, tidak diperlukan proses instalasi yang rumit, dan dapat dijalankan di perangkat komputer tanpa perlu instalasi program tertentu. Sedangkan dilihat dari aspek komunikasi visualnya, media pembelajaran yang dikembangkan sudah komunikatif, navigasi dalam pengoperasian media tidak membingungkan, audio dan visual, seperti backsound, sound effect, Layout, tipografi, serta warna sudah baik dan menarik.

Selain penilaian dari ahli perangkat pembelajaran, validitas media pembelajaran juga ditentukan dari penilaian oleh ahli materi. Validitas Media Pembelajaran berdasarkan hasil penilaian ahli materi berada pada kriteria baik, dengan rata-rata skor 2,66. Ahli materi menilai validitas media pembelajaran dari aspek desain pembelajaran. Secara umum materi yang disajikan dalam media pembelajaran dengan kompetensi dasar sudah sesuai, kontekstualitasnya sudah baik, pembelajaran dalam media sudah sistematis, alur logis, dan jelas, sudah memuat contoh soal, pembahasan, dan latihan soal, materi pelajaran bisa direview ulang, dan isi media pembelajaran secara keseluruhan dapat memotivasi siswa dalam pembelajaran.

Berdasarkan hasil penilaian dari ahli media pembelajaran dan ahli desain pembelajaran menunjukan bahwa media yang dikembangkan termasuk dalam kategori "valid" karena memenuhi kelayakan dari ahli media pembelajaran dan ahli desain pembelajaran sesuai dengan yang telah ditetapkan pada Bab III. Penilaian ahli media pembelajaran dan ahli desain pembelajaran diperoleh rata-rata skor sebesar 2,68.

Kepraktisan Media Pembelajaran Persamaan Linier Dua variabel berdasarkan hasil analisis angket respons siswa berada pada kriteria baik, dengan rata-rata skor 3,24. Kepraktisan Media Pembelajaran Persamaan Linier Dua Variabel berdasarkan hasil analisis angket respons guru berada pada kriteria baik, dengan rata-rata skor 3,30.

Kepraktisan media pembelajaran yang dikembangkan dalam penelitian ini diukur berdasarkan keterlaksanaan media tersebut di kelas. Media pembelajaran yang dikembangkan dirancang dengan navigasi yang mudah, dan disertai petunjuk yang jelas terkait penggunaan media. Tampilan awal dan jenis huruf yang digunakan dibuat sebaik mungkin untuk menarik perhatian siswa. Bahasa yang digunakan dalam media pembelajaran dibuat komunikatif dan menggunakan Bahasa Indonesia yang baik dan benar. Secara umum berdasarkan analisis angket respons siswa dan guru diketahui bahwa pembelajaran menggunakan media yang dikembangkan menarik dan motivasi belajar siswa setelah mengikuti pembelajaran menggunakan media sudah baik.

Media pembelajaran yang dikembangkan memenuhi kriteria efektif untuk digunakan sebagai media pembelajaran. Hasil ini sejalan dengan penelitian yang dilakukan oleh I Gusti 
Lanang Adhi Wirasena (2012) dan Aprilia Dinda Permata (2014), di mana dalam penelitian mereka diketahui bahwa media pembelajaran interaktif layak dikembangkan dalam pembelajaran matematika.

Berdasarkan kegiatan uji coba terbatas terhadap 15 orang siswa, diperoleh ketuntasan klasikal siswa dalam menjawab tes evaluasi setelah menggunakan Media pembelajaran adalah 93,33\% dengan KKM sebesar 75. Menurut Trianto (2010:241), "suatu kelas dikatakan tuntas belajarnya (ketuntasan klasikal) jika dalam kelas tersebut terdapat $\geq 85 \%$ siswa yang telah tuntas belajarnya".

\section{Simpulan dan Saran}

Berdasarkan pembahasan yang telah diuraikan dapat disimpulkan beberapa hal sebagai berikut.

Rancangan media pembelajaran dalam penelitian ini disusun secara sederhana, jelas, dan memuat beberapa hal, antara lain: 1) kompetensi dasar dan indikator pembelajaran yang ingin dicapai dalam pembelajaran menggunakan media yang dikembangkan; 2) butirbutir materi yang dibelajarkan; 3) deskripsi kegiatan pada setiap halaman; 4) komponenkomponen yang termuat dalam setiap halaman; 5) desain tampilan (layout) setiap halaman. Rancangan media pembelajaran sudah diimplementasikan menggunakan GeoGebra sebagai aplikasi pembuat media eksplorasi, Lectora Inspire sebagai aplikasi pembuat layout dan latihan soal. Hasil implementasi adalah sebuah program media pembelajaran persamaan linier dua variabel materi bangun ruang sisi datar yang dikemas dalam format file executable (.exe) dan dapat dijalankan tanpa perlu menginstal program tertentu. Media pembelajaran yang dikembangkan telah diuji validitas, kepraktisan, dan keefektifannya. Hasil uji tersebut menyatakan bahwa media pembelajaran yang dikembangkan memenuhi kriteria valid, praktis, dan efektif sehingga dapat diterima dan layak digunakan sebagai media pembelajaran pada materi persamaan linier dua variabel.

Berdasarkan hasil penelitian yang telah diperoleh dapat disarankan beberapa hal sebagai berikut. Guru disarankan untuk memanfaatkan media pembelajaran yang dikembangkan sebagai penunjang pembelajaran berbasis komputer sehingga proses pembelajaran lebih bervariasi. Siswa disarankan untuk menggunakan media pembelajaran yang dikembangkan sebagai media untuk belajar materi persamaan linier dua variabel. Dengan digunakannya media pembelajaran yang dikembangkan, siswa akan mendapatkan pengalaman belajar yang baru dan menarik. Peneliti lain yang tertarik melanjutkan penelitian ini, dapat mengembangkan media supaya dapat merekam pengalaman atau aktivitas belajar siswa saat menggunakan media, serta pembentukan bank soal sehingga soal latihan dapat diacak setiap kali pemunculan soal. Peneliti lain yang tertarik disarankan untuk melakukan penelitian dengan lingkup yang lebih luas, misalnya melakukan penelitian eksperimen sebagai uji coba media.

\section{Daftar Pustaka}

Erman Suherman, dkk. 2003. Strategi Pembelajaran Matematika Kontemporer. Bandung: UPI.

Departemen Pendidikan Nasional. 2003. Undang-Undang Nomor 20 Tahun 2003, Tentang Sistem Pendidikan Nasional. Jakarta: Depdiknas.

Fahy, Patrick J. 2005. Planning for Multimedia Learning. Dalam Sanjaya Mishra, Ramesh C. Sharma (Eds). Interactive Multimedia in Education and Training (hlm. 1-24). United States: Idea Group Inc.

Hohenwarter, J. dkk. 2008. "Introducing Dynamic Mathematics Software to Secondary School Teachers: The Case of GeoGebra". Journal of Computers in Mathematics and Science Teaching (2008).

Kemendikbud. 2013. Lampiran Peraturan Menteri Pendidikan dan Kebudayaan RI Nomor 65 Tahun 2013 tentang Standar Proses Pendidikan Dasar dan Menengah. Jakarta: Kementerian Pendidikan dan Kebudayaan 
Lanang Adhi Wirasena, I Gusti. Pengembangan Multimedia Interaktif Tentang Pengenalan Bangun Datar dengan Model ADDIE pada Mata Pelajaran Matematika Siswa Kelas IV di SD Negeri 1 Sibetan Semester Genap Tahun Pelajaran 2011-2012. Skripsi (tidak diterbitkan). Jurusan Teknologi Pendidikan, FIP Undiksha.

Marsigit. (2013). Tantangan dan Harapan Kurikulum 2013 Bagi Pendidikan Matematika. Makalah disajikan dalam Seminar Nasional Matematika dan Pendidikan Matematika, di Universitas PGRI Yogyakarta.

Musfiqon. 2012. Pengembangan Media \& Sumber Pembelajaran. Jakarta: Prestasi Pustaka.

Punaji Setyosari. 2010. Metode Penelitian Pendidikan dan Pengembangan, Edisi Pertama, Cekatakan Ke-1. Jakarta: Kencana

Tegeh, I M. dan I M. Kirna. 2010. Metode Penelitian Pengembangan Pendidikan. Singaraja: Universitas Pendidikan Ganesha.

Trianto.2010. Mendesain Model Pembelajaran Inovatif-Progresif, Konsep, Landasan, dan Implementasinya pada Kurikulum Tingkat Satuan Pendidikan (KTSP), Edisi Pertama, Cetakan Ke-2. Jakarta: Kencana 